\title{
KEMAMPUAN MENULIS TEKS NARASI TENTANG PENGALAMAN LIBUR SEKOLAH SISWA KELAS VII SMP NEGERI 1 BERMANI ILIR KABUPATEN KEPAHIANG
}

\author{
Suci Rahmadani ${ }^{1}$, Suhartono ${ }^{2}$, dan M. Arifin ${ }^{3}$ \\ ${ }^{1,2,3}$ Program Studi Pendidikan Bahasa dan Sastra Indonesia \\ Jurusan Pendidikan Bahasa dan Seni \\ FKIP Universitas Bengkulu \\ s.rahmadani67@yahoo.com
}

\begin{abstract}
Abstrak
Tujuan penelitian ini untuk mengetahui kemampuan menulis teks narasi tentang pengalaman libur sekolah siswa kelas VII SMP Negeri 1 Bermani Ilir Kabupaten Kepahiang. Penelitian ini menggunakan metode deskriptif dengan pendekatan kuantitatif. Populasi dalam penelitian ini semua siswa kelas VII SMP Negeri 1 Bermani Ilir Kabupaten Kepahiang yang berjumlah 151 orang. Sedangkan sampel penelitian ini menggunakan teknik random sampling sebanyak $22 \%$ dari jumlah populasi, yaitu 33 orang siswa. Teknik pengumpulan data menggunakan teknik tes. Kemampuan menulis teks narasi ini akan dinilai dari lima aspek, yaitu isi, struktur, kebahasaan, diksi, dan ejaan. Teknik analisis data yang digunakan dalam penelitian ini yaitu, statistik sederhana dengan menghitung rata-rata. Hasil penelitian ini menunjukkan bahwa rata-rata kemampuan menulis teks narasi tentang pengalaman libur sekolah siswa kelas VII SMP Negeri 1 Bermani Ilir Kabupaten Kepahiang adalah 55,15 (kurang). Adapun rata-rata kemampuan menulis teks narasi tentang pengalaman libur sekolah berdasarkan aspek isi adalah 17,62 (cukup), rata-rata kemampuan menulis teks narasi dari aspek struktur adalah 15,19 (cukup), rata-rata kemampuan menulis teks narasi dari aspek kebahasaan adalah 10,10 (cukup), rata-rata kemampuan menulis teks narasi dari aspek diksi adalah 7,09 (cukup), rata-rata kemampuan menulis teks narasi dari aspek ejaan adalah 5,13 (cukup). Bagi siswa, hendaknya lebih banyak membaca materi dan contoh teks narasi untuk menambah kosa kata. Bagi guru, hendaknya lebih menekankan pembelajaran mengenai penggunaan ejaan.
\end{abstract}

\section{Kata kunci: Kemampuan, menulis, teks narasi.}

\begin{abstract}
The purpose of this study was to determine the ability to write narrative text about the school holiday experience of the seventh grade students of SMP Negeri 1 Bermani llir Kepahiang Regency. This research uses descriptive method with quantitative approach. The population in this study are all students of class VII SMP Negeri 1 Bermani Ilir Kepahiang District, amounting to 151 people. While the sample of this study using random sampling technique as much as $22 \%$ of the total population, which is 33 students. Technique of collecting data using test technique. The ability to write narrative text will be assessed from five aspects, namely content, structure, language, diction, and spelling. Data analysis technique used in this research that is, simple statistic with calculate mean. The results of this study indicate that the average ability to write narrative text about the school holiday experience of students of grade VII SMP Negeri 1 Bermani llir Kepahiang Regency is 55.15 (less). The average ability to write narrative text on school experience based on the content
\end{abstract}


aspect is 17.62 (enough), the average ability to write narrative text from the aspect of the structure is 15.19 (enough), the average ability to write narrative text from the aspect Linguistic is 10.10 (enough), the average ability of writing narrative text from the aspect of diction is 7.09 (enough), the average ability of writing narrative text from aspect of spelling is 5.13 (enough). For students, should read more material and examples of narrative text to add vocabulary. For teachers, more emphasis should be given to learning about spelling use.

Keywords: Ability, writing, narrative text.

\section{PENDAHULUAN}

Menulis sangat penting bagi siswa dalam proses pembelajaran, karena menulis merupakan salah satu keterampilan berbahasa yang dibutuhkan untuk meningkatkan kualitas pembelajaran. Keterampilan menulis merupakan salah satu komponen dalam keterampilan berbahasa selain menyimak, berbicara, dan membaca.

Dengan penguasaan keterampilan menulis, diharapkan siswa dapat mengungkapkan gagasan, pikiran, dan perasaan yang dimilikinya setelah menjalani proses pembelajaran dalam berbagai jenis tulisan, baik fiksi maupun nonfiksi. Asumsinya, pengungkapan tersebut merupakan peresapan, pemahaman, dan tanggapan siswa terhadap berbagai hal yang diperoleh dalam proses pembelajaran. Dengan demikian, segala informasi, ilmu pengetahuan, dan berbagai kecakapan yang diperoleh siswa dalam pembelajaran tidak akan sekedar menjadi hafalan yang mudah dilupakan sesaat setelah siswa menjalani tes.

Menulis memiliki banyak manfaat diantaranya meningkatkan kecerdasan, pengembangan daya inisiatif dan kreativitas, penumbuhan keberanian dan pendorongan kemauan dan kemampuan mengumpulkan informasi.

Kondisi pembelajaran menulis saat ini belum dicapai secara maksimal oleh siswa. Tidak tercapainya pembelajaran menulis karena rendahnya tingkat penguasaan kosa kata sebagai akibat rendahnya minat baca, kurangnya penguasaan keterampilan mikrobahasa, seperti penggunaan tanda baca, kaidahkaidah penulisan, diksi, penyusunan kalimat dengan struktur yang benar, sampai penyusunan paragraf, kesulitan menemukan metode pembelajaran menulis yang sesuai dengan kondisi dan kemampuan siswa, serta ketiadaan atau keterbatasan media pembelajaran menulis yang efektif.

Meskipun keterampilan menulis sangat diperlukan dalam kehidupan, tetapi padakenyataannya pengajaran keterampilan menulis kurang mendapat perhatian.Membaca dan menulis yang dulu merupakan pelajaran dan latihan pokok kini kurang mendapat perhatian, baik dari para siswa maupun para guru. Pelajaran mengarang sebagai salah satu aspek dalam pengajaran bahasa Indonesia kurang ditangani secara sungguh-sungguh.

Menurut Dalman (2014:3) menulis sangat penting karena menulis merupakan sebuah proses menuangkan gagasan dalam bentuk bahasa tulis dalam tujuan, misalnya memberitahu, meyakinkan, atau menghibur. Menurut Tarigan (2013:3) menulis merupakan suatu keterampilan berbahasa yang dipergunakan untuk berkomunikasi secara tidak langsung, tidak secara tatap muka dengan orang lain.

Pembelajaran berbasis teks dalam mata pelajaran Bahasa Indonesia lebih menekankan pada siswa untuk memahami berbagai jenis teks dan menuntut siswa 
untuk mahir menulis. Adapun teks yang diajarkan dalam kurikulum 2013 yaitu teks deskripsi, teks narasi, teks prosedur, teks laporan hasil observasi, puisi rakyat, fabel/ legenda, surat pribadi dan surat dinas.

Teks narasi merupakan salah satu bentuk teks yang tepat untuk dipelajari bagi siswa kelas VII, mengingat unsur-unsur narasi yang mencakup unsur kronologis di dalamnya, sehingga siswa dapat membuat karangan sesuai urutan kejadian yang diketahuinya.Namun dalam kenyataannya, masih banyak ditemukan permasalahan dalam pembelajaran bahasa Indonesia, terutama untuk kegiatan menulis di sekolah.

Keraf (2007:136) mengatakan bahwa karangan narasi merupakan suatu bentuk karangan yang sasaran utamanya adalah tindak tanduk yang dijalin dan dirangkai menjadi sebuah peristiwa yang terjadi dalam suatu kesatuan waktu. Atau dapat juga dirumuskan dengan cara lain; narasi adalah suatu bentuk karangan yang berusaha menggambarkan sejelas-jelasnya kepada pembaca suatu peristiwa yang telah terjadi.

Narasi (penceritaan atau pengisahan) adalah ragam wacana yang menceritakan proses kejadian suatu peristiwa. Sasarannya adalah memberikan gambaran yang sejelas-jelasnya kepada pembaca mengenai fase, urutan, langkah, atau rangkaian terjadinya sesuatu hal (Saddhono, 2012:101).

Secara sederhana, narasi dikenal sebagai cerita.Pada narasi terdapat peristiwa atau kejadian dalam satu urutan waktu. Dalam kejadian itu ada pula tokoh yang menghadapi suatu konflik.Ketiga unsur berupa kejadian, tokoh dan konflik merupakan unsur pokok sebuah narasi.Jika ketiga unsur itu bersatu, ketiga unsur itu disebut plot atau alur.Jadi, narasi adalah cerita yang dipaparkan berdasarkan plot atau alur. Secara singkat untuk dapat menulis karangan narasi memerlukan kemampuan dan penguasaan bahasa yang baik, agar seorang penulis karangan dapat mengungkapkan kejadian menggunakan bahasa yang baik dan mudah dipahami orang lain.

\section{METODE}

Metode dalam penelitian ini ialah metode deskriptif kuantitatif. Populasi dalam penelitian ini adalah semua siswa kelas VII SMP Negeri 1 Bermani Ilir Tahun Ajaran 2016/2017 yang berjumlah 151 orang. Sampel dalam penelitian ini yaitu, peneliti megambil $22 \%$ dari jumlah populasi yang ingin diteliti, sehingga sampel dalam penelitian ini berjumlah 33 orang.

\section{HASIL DAN PEMBAHASAN}

Berdasarkan data yang telah terkumpul, hasil penelitian ini berbentuk skor kemampuan menulis teks narasi tentang pengalaman libur sekolah siswa kelas VII SMP Negeri 1 Bermani Ilir Kabupaten Kepahiang yang telah ditulis siswa. Data tersebut berupa kemampuan menulis teks narasi tentang pengalaman libur sekolah dan juga data yang terdiri dari 5 aspek yaitu, kemampuan menulis teks narasi dari aspek isi, kemampuan menulis teks narasi dari aspek struktur, kemampuan menulis teks narasi dari aspek kebahasaan, kemampuan menulis teks narasi dari aspek diksi, kemampuan menulis teks narasi dari aspek ejaan.

Kemampuan Menulis Teks Narasi Tentang Pengalaman Libur Sekolah Siswa Kelas VII SMP Negeri 1 Bermani Ilir Kabupaten Kepahiang. Berdasarkan hasil analisis data kemampuan menulis teks narasi tentang pengalaman libur sekolah siswa kelas VII SMPN 1 Bermani Ilir Kabupaten Kepahiang dikategorikan kurang. Karena skor akhir yang diperoleh sebesar 55,15 dan apabila dimasukan ke dalam rentang skor skala lima maka berada pada rentang skor 45-55. Kemampuan 
menulis teks narasi tentang pengalaman libur sekolah siswa kelas VII SMPN 1 Bermani Ilir Kabupaten Kepahiang terbagi atas: 3 orang siswa $(9,1 \%)$ dengan kategori nilai sangat baik, 4 orang siswa (12,1\%) dengan kategori nilai baik, 8 orang siswa $(24,2 \%)$ dengan kategori nilai cukup, 6 orang siswa $(18,1 \%)$ termasuk dalam kategori kurang, dan 12 orang siswa (36,3 $\%)$ termasuk dalam kategori sangat kurang. Selain itu, dari analisis data yang telah dilakukan pada kemampuan menulis teks narasi tentang pengalaman libur sekolah siswa kelas VII SMPN 1 Bermani Ilir Kabupaten Kepahiang, siswa masih kesulitan dalam menulis teks narasi dalam penggunaan diksi, penggunaan bahasa maupun ejaan dalam membuat teks narasi. Pada kemampuan menulis teks narasi yang dilihat pada aspek diksi, kecendrungan siswa kesulitan memilih pilihan kata yang sesuai untuk diguanakan dalam teks narasi yang mereka buat. Kemampuan menulis teks narasi yang dilihat dari aspek penggunaan bahasa, kecendrungan siswa kesulitan membuat kalimat efektif yang akan digunakan dalam menulis teks narasi. Sedangkan dalam penggunaan ejaan siswa juga masih kesulitan dalam penggunaan tanda baca..

Kemampuan Menulis Teks Narasi Aspek Isi. Berdasarkan hasil analisis data, kemampuan menulis teks narasi tentang pengalaman libur sekolah siswa kelas VII SMPN 1 Bermani Ilir Kabupaten Kepahiang dari aspek isi dikategorikan cukup.karena rata-rata yang diperoleh sebesar 17,62 dan apabila dimasukkan ke dalam tabel frekuensi skala lima maka berada pada rentang skor 13-18. Kemampuan menulis teks narasi dari aspek isi terbagi atas: 5 orang siswa $(15,1 \%)$ termasuk dalam kategori sangat baik, 7 orang siswa (21,2\%) termasuk dalam kategori baik, 11 orang siswa (33,3 \%)termasuk dalam kategori cukup, 7 orang siswa (21,2 \%)termasuk dalam kategori kurang, dan 3 orang siswa
(9 \%) termasuk dalam kategori sangat kurang. Selain itu, dari hasil analisis data yang telah dilakukan pada aspek isi, kebanyakan siswa sudah dapat membuat teks narasi secara baik, sesuai dengan kategori penilaian dalam aspek isi, seperti informasi yang disajikan lengkap, jelas, padat, dan sesuai dengan topik yang ditetapkan. Hanya saja ada beberapa siswa yang kesulitan dalam menuangkan informasi secara lengkap, jelas, dan padat.

Kemampuan Menulis Teks Narasi Aspek Struktur. Berdasarkan hasil analisis data, kemampuan menulis teks narasi tentang pengalaman libur sekolah siswa kelas VII SMPN 1 Bermani Ilir Kabupaten Kepahiang dari aspek struktur dikategorikan cukup.karena rata-rata yang diperoleh sebesar 15,19 dan apabila dimasukkan ke dalam tabel frekuensi skala lima maka berada pada rentang skor 11-15. Kemampuan menulis teks narasi dari aspek struktur terbagi atas: 2 orang siswa (6\%) termasuk dalam kategori sangat baik, 14 orang siswa $(42,4 \%)$ termasuk dalam kategori baik, 10 orang siswa (30,3 \%) termasuk dalam kategori cukup, 6 orang siswa (18,1 \%)termasuk dalam kategori kurang, dan 1 orang siswa (3\%)termasuk dalam kategori sangat kurang. Selain itu, dari hasil analisis data yang telah dilakukan pada aspek struktur, sebagian siswa sudah dapat membuat teks narasi secara runtut, diorganisasikan secara baik, hanya saja masih ada siswa yang kesulitan menulis teks narasi secara terstruktur.

Kemampuan Menulis Teks Narasi Aspek Kebahasaan. Berdasarkan hasil analisis data, kemampuan menulis teks narasi tentang pengalaman libur sekolah siswa kelas VII SMPN 1 Bermani Ilir Kabupaten Kepahiang dari aspek penggunaan bahasa dikategorikan cukup. Rata-rata yang diperoleh sebesar 10,10 dan apabila dimasukan ke dalam rentang skor skala lima maka berada pada rentang skor 9-12. Kemampuan menulis teks narasi dari 
aspek kebahasaan terbagi atas: 1 orang siswa (3\%) dengan kategori nilai sangat baik, 3 orang siswa (9\%) dengan kategori nilai baik, 16 orang siswa $(48,4 \%)$ dengan kategori nilai cukup, 12 orang siswa $(36,3$ $\%)$ dengan kategori nilai kurang dan 1 orang siswa (3\%) termasuk dalam kategori sangat kurang. Dari analisis data yang telah dilakukan dari aspek kebahasaan diketahui bahwa siswa sudah dapat menulis teks narasi dari aspek kebahasaan, seperti menggunakan kalimat secara efektif serta pemakaian kata perintah dan konjungsi secara tepat.Akan tetapi ada sebagian siswa juga masih kesulitan menggunakan kalimat yang efektif dalam teks narasi.

Kemampuan Menulis Teks Narasi Aspek Diksi. Berdasarkan hasil analisis data, kemampuan menulis teks narasi tentang pengalaman libur sekolah siswa kelas VII SMPN 1 Bermani Ilir Kabupaten Kepahiang dari aspek diksi dikategorikan cukup, karena rata-rata yang diperoleh sebesar 7,09 dan apabila dimasukan ke dalam tabel frekuensi skala lima maka berada pada rentang skor 7-9. Kemampuan menulis teks narasi dari aspek diksi terbagi atas: 1 orang siswa (3\%) dengan kategori nilai sangat baik, 3 orang siswa (9\%) dengan kategori nilai baik, 8 orang siswa (24,2 \%) dengan kategori nilai cukup, 20 orang siswa $(60,6$ \%) dengan kategori nilai kurang dan 1 orang siswa (3\%) termasuk dalam kategori sangat kurang. Berdasarkan analisis data yang telah dilakukan dari menulis teks narasi dari aspek diksi dapat diketahui hanya ada sebagian siswa yang sudah dapat menggunakan pilihan kata yang tepat.Akan tetapi ada juga siswa yang masih kesulitan dalam memilah kata yang digununakan dalam teks narasi.

Kemampuan Menulis Teks Narasi Aspek Ejaan. Berdasarkan hasil analisis data, kemampuan menulis teks narasi tentang pengalaman libur sekolah siswa kelas VII SMPN 1 Bermani Ilir Kabupaten Kepahiang dari aspek ejaan dikategorikan cukup.karena rata-rata yang diperoleh sebesar 5,13 dan apabila dimasukan ke dalam rentang skor skala lima maka berada pada rentang skor 5-6. Kemampuan menulis teks narasi dari aspek ejaan terbagi atas: 1 orang siswa (3\%) dengan kategori nilai sangat baik, 5 orang siswa $(15,1 \%)$ dengan kategori nilai baik, 13 orang siswa $(39,3 \%)$ dengan kategori nilai cukup, 10 orang siswa $(30,3 \%)$ termasuk dalam kategori kurang, 4 orang siswa $(12,1$ $\%)$ termasuk dalam kategori sangat kurang. Dari analisis data yang telah dilakukan dari aspek ejaan diketahui bahwa siswa kelas VII SMPN 1 Bermani Ilir Kabupaten Kepahiang sebagian dapat menguasai aturan ejaan yang disempurnakan, dan juga ada beberapa siswa yang menjadi sampel dalam penelitian ini kesulitan dalam menentukan penggunaan huruf kapital dan tanda baca. Misalnya ada beberapa siswa menggunakan huruf kapital setiap awal kalimat yang ia tulis dan ada juga siswa yang tidak menggunakan huruf kapital pada huruf awal pada bagian judul. Selain itu juga, ada juga beberapa siswa yang tidak menggunakan tanda baca titik pada akhir kalimat.

\section{PENUTUP \\ Kesimpulan}

Berdasarkan hasil penelitian dan pembahasan, dapat disimpulkan bahwa kemampuan menulis teks narasi tentang pengalaman libur sekolah siswa kelas VII SMP Negeri 1 Bermani Ilir Kabupaten Kepahiang dengan skor rata-rata yang diperoleh siswa yaitu 55,15 termasuk dalam kategori kurang, karena siswa masih kesulitan menulis teks narasi dalam penggunaan diksi, penggunaan bahasa maupun ejaan dalam membuat teks narasi.

Secara rinci kemampuan menulis teks narasi tentang pengalaman libur sekolah siswa kelas VII SMP Negeri 1 Bermani Ilir Kabupaten Kepahiang dari 
masing-masing aspek dapat disajikan berikut:

1. Pada aspek isi, kemampuan menulis teks narasi memperoleh rata-rata 17,62 berada pada kategori cukup.

2. Pada aspek struktur, kemampuan menulis teks narasi memperoleh ratarata 15,19 berada pada kategori cukup.

3. Pada aspek kebahasaan, kemampuan menulis teks narasi siswa memperoleh rata-rata 10,10 berada pada kategori cukup.

4. Pada aspek diksi, kemampuan menulis teks narasi memperoleh rata-rata 7,09 berada pada kategori cukup.

5. Pada aspek ejaan, kemampuan menulis teks prosedur siswa memperoleh ratarata 5,13 berada pada kategori cukup.

\section{Saran}

Berdasarkan hasil penelitian yang dilakukan, penulis menyampaikan beberapa saran yang berkaitan dengan penelitian ini, sebagai berikut ini.

1. Bagi siswa, hendaknya lebih banyak membaca materi dan contoh teks narasi untuk menambah kosa kata, wawasan serta pengetahuan mengenai menulis teks narasi. selain itu, siswa hendaknya lebih belajar dan membaca lagi mengenai pedoman umum penulisan ejaan.

2. Bagi guru, hendaknya guru menekankan pada pembelajaran mengenai penggunaan ejaan seperti penulisan huruf kapital dan tanda baca. Selain itu, guru juga harus banyak memberikan banyak latihan membuat teks narasi dan memberikan banyak contoh teks narasi dan kepada siswa untuk menambah kosa kata siswa.

\section{DAFTAR PUSTAKA}

Dalman. 2014. Keterampilan Menulis. Jakarta: PT RajaGrafindo Persada.

Keraf, Gorys. 1982. Argumentasi dan Narasi. Jakarta: PT Gramedia.

Saddhono, Kundharu. 2014. Pembelajaran Keterampilan Berbahasa Indoensia. Yogyakarta: GRAHA ILMU.

Suhartono. 2005. Dasar-Dasar Menulis Karangan. Bengkulu: Unit Penerbitan FKIP Universitas Bengkulu.

Tarigan, H.G. 2013. Menulis Sebagai Suatu Keterampilan Berbahasa. Bandung: Angkasa. 